\title{
Analisis Pembuktian Kasus Tindak Pidana Korupsi Melalui Pemanfaatan Laporan Audit Forensik Dan Pemberian Keterangan Ahli Oleh Auditor Forensik Di Provinsi Sulawesi Utara
}

\author{
NASRULLAH ${ }^{1}$, LINTJE KALANGI ${ }^{2}$, HENDRIK GAMALIEL ${ }^{3}$ \\ 1,2,3 Program Magister Akuntansi, Fakultas Ekonomi dan Bisnis Universitas Sam Ratulangi \\ email: nasrul33@gmail.com¹, lintje_kalangi@unsrat.ac.id², hendrik_gamaliel@unsrat.ac.id ${ }^{3}$
}

\begin{abstract}
The research aims to analyse the process of utilizing forensic audit report by police, prosecutors and judges in North Sulawesi province. This is an exploratory qualitative research. Data were obtained by in-depth interviews, observations and documentation studies. The key informant is set by purposive sampling with the condition to meet the criteria set to obtain precise and accurate information. Interviews were transcribed into data transcriptions, analyzed, coded, and categorized into themes. Data were analyzed by content analysis. The results showed that the utilization of forensic audit reports by police, prosecutors and judges in North Sulawesi province, through the audit report, both the investigative Audit report (LHAI) and the Audit result report of the loss calculation National finance (LHAPKKN) are formally needed by both the investigation team and the investigator team, both as preliminary evidence and further evidence (proof of letter in the indictment file). Not all investigation activities and investigation activities end up in the judicial process. Some cases, can be terminated at each stage with various reasons and conditions such as: the return of financial loss to the state, the case is handled by other investigation agencies which are KPK or prosecutors, suspects or related parties (Crown witnesses) passed away, or certain subjective reasons. Result also shows that forensic audit report which is not utilised by investigator does not breach the rules in proving the crime.
\end{abstract}

Keywods: Forensic audit, auditor, corruption criminal, investigation, trial, expert description.

Abstrak. Penelitian ini bertujuan untuk menganalisis proses pemanfaatan laporan hasil audit forensik oleh Polisi, Jaksa dan Hakim di Provinsi Sulawesi Utara. Penelitian ini menggunakan metode kualitatif dengan pendekatan eksploratif deskriptif. Data diperoleh dengan teknik wawancara mendalam, observasi dan studi dokumentasi. Informan kunci ditetapkan secara purposive sampling dengan syarat memenuhi kriteria yang ditetapkan untuk mendapatkan informasi yang tepat dan akurat. Hasil wawancara di-transcribe menjadi transkrip data, kemudian dianalisis, diberi kode, dan dikategorikan ke dalam tema. Analisis data menggunakan analisis isi. Hasil penelitian menunjukan bahwa pemanfaatan laporan hasil audit forensik oleh Polisi, Jaksa dan Hakim di Provinsi Sulawesi Utara, melalui Laporan hasil audit, baik Laporan Hasil Audit Investigatif (LHAI) maupun Laporan Hasil Audit Perhitungan Kerugian Keuangan Negara (LHAPKKN) secara formal sangat dibutuhkan oleh tim penyelidik maupun tim penyidik, baik sebagai bukti awal maupun bukti lanjutan (bukti surat dalam berkas dakwaan). Tidak semua kegiatan penyelidikan dan kegiatan penyidikan berakhir di proses peradilan. Sebagian dari kasus tersebut dapat dihentikan baik pada tahap penyelidikan maupun pada tahap penyidikan dengan berbagai alasan dan kondisi yakni: pengembalian kerugian keuangan Negara, kasus tersebut ditangani instansi penyidik lainnya yaitu KPK atau kejaksaan, tersangka atau pihak terkait (saksi mahkota) meninggal dunia, atau alasan subjektif tertentu. Hasil penelitian juga menunjukkan bahwa laporan hasil audit forensik yang tidak dimanfaatkan oleh instansi penyidik (penegak hukum) bukan merupakan pelanggaran hukum dalam proses pembuktian tindak pidana.

Kata Kunci: Audit forensic, auditor forensic, tindak pidana korupsi, penyelidikan, penyidikan, persidangan, keterangan ahli.

\section{Pendahuluan}

Dalam praktiknya di BPKP, baik di Pusat maupun di Perwakilan, audit investigasi dapat dilakukan melalui peningkatan/pemanfaatan laporan hasil audit umum (audit operasional dan audit kinerja dan penugasan lain yang relevan), yang dilakukan oleh BPKP sendiri dan berdasarkan atas permintaan dari penyidik, baik penyidik dari kepolisian maupun kejaksaan. Jika audit investigasi atas permintaan penyidik ditujukan untuk membuktikan ada atau tidaknya penyimpangan yang diduga telah terjadi, dan status kasus masih dalam tahap penyelidikan. Sedangkan untuk audit perhitungan kerugian keuangan Negara dilakukan pada status kasus telah dalam tahap penyidikan dan kemudian dilimpahkan ke proses peradilan, Achsin (2010) mengungkapkan bahwa penugasan audit investigatif mengharuskan auditor untuk melakukan upaya ekstra, yakni auditor harus masuk 
pada kedalaman persoalan. Hypothetical construction of crime menjadi radar utama dalam mencari, menemukan dan mengumpulkan bahan bukti hingga mengungkap kasus kecurangan (fraud) atau korupsi.

Provinsi Sulawesi Utara terdapat beberapa kasus tindak pidana korupsi yang diajukan ke persidangan dan menyita perhatian publik lokal maupun Nasional, antara lain kasus pengadaan penerangan jalan umum dengan sistem solar cell Kota Manado tahun $2014^{1}$ dan kasus pemecah ombak Likupang, Kabupaten Minahasa Utara ${ }^{2}$, untuk kasus solar cell dibuktikan dengan bantuan audit investigatif dari BPKP Perwakilan Provinsi Sulawesi Utara kemudian ditahap penyidikan menggunakan laporan hasil audit perhitungan kerugian negara serta pemberian keterangan ahli di pengadilan, sedangakan untuk kasus pembangunan pemecah ombak Likupang menggunakan laporan hasil audit perhitungan kerugian keuangan negara serta pemberian keterangan ahli didepan pengadilan.

Hasil laporan audit investigasi biasanya dimanfaatkan oleh para penyidik, baik penyidik dari Kepolisian maupun Kejaksaan untuk membantu dalam proses penyidikan kasus tindak pidana korupsi, kemudian untuk dapat menjadi bukti dalam berkas dakwaan/penuntutan dilakukan audit atas perhitungan kerugian keuangan Negara, laporan hasil audit Perhitungan Kerugian Keuangan Negara merupakan salah satu bukti surat dalam berkas dakwaan/penuntutan, berikut Tabel 1 pemanfaatan laporan audit forensik pada Perwakilan BPKP Provinsi Sulawesi Utara oleh penyidik Tipikor.

Tabel 1

Pemanfaatan Laporan Audit Forensik Oleh Penyidik

\begin{tabular}{|c|c|c|c|c|c|c|}
\hline & \multicolumn{3}{|c|}{ Tahap Penyelidikan } & \multicolumn{3}{c|}{ Tahap Penyidikan } \\
\cline { 2 - 7 } & LHAI & Penyidikan & $\begin{array}{c}\text { Tidak Naik ke } \\
\text { Tahap } \\
\text { Penyidikan }\end{array}$ & LHAPKKN & Peradilan & $\begin{array}{c}\text { Tidak } \\
\text { Masuk } \\
\text { Persidangan }\end{array}$ \\
\hline 2015 & 4 & 2 & 2 & 12 & 6 & 6 \\
\hline 2016 & 4 & 1 & 3 & 9 & 6 & 3 \\
\hline 2017 & 3 & 1 & 2 & 10 & 5 & 5 \\
\hline Jumlah & 12 & 4 & 7 & 31 & 17 & 14 \\
\hline
\end{tabular}

Tabel 1 dapat menjelaskan bahwa dalam rentang waktu tiga tahun sejak tahun 2015 sampai dengan tahun 2017 terdapat 12 Laporan Hasil Audit Investigatif (LHAI) yang terbit, namun dari jumlah tersebut hanya 4 LHAI atau 33,33\% yang naik ke tahap selanjutnya yaitu tahap penyidikan, 7 LHAI atau 58,33\% tidak dimanfaatkan oleh penyidik, dan dari 31 LHAPKKN, hanya 17 LHAPKKN atau $54,84 \%$ yang naik ke tahap selanjutnya yaitu tahap persidangan di Pengadilan Negeri Manado, 14 LHAPKKN atau 45,16\% tidak dimanfaatkan oleh penyidik.

Penjelasan Tabel 1 dapat menjelaskan bahwa banyak laporan hasil audit forensik yang diterbitkan Perwakilan BPKP Provinsi Sulawesi Utara tidak atau belum dimanfaatkan oleh instansi penyidik. Padahal sebelumnya instansi penyidik yang meminta untuk dilakukan audit forensik, baik audit investigatif maupun audit perhitungan kerugian keuangan Negara. Bagi Perwakilan BPKP Provinsi Sulawesi Utara tidak ada kewajiban untuk mendorong atau memonitor proses penyidikan maupun proses persidangan karena berada pada ranah kewenangan yang berbeda antara instansi penyidik dan instansi auditor.

Atas permasalahan tersebut, peneliti melakukan analisis pada instansi penyidik dan instansi peradilan, tujuannya untuk mencari informasi terhadap permasalahan tidak dimanfaatkan secara maksimal hasil audit forensik yang diterbitkan Perwakilan BPKP Provinsi Sulawesi Utara. Jika terdapat kendala, apakah kendala tersebut adalah kendala yang disebabkan kualitas hasil audit seperti: laporan tidak jelas, sumir dan faktor kualitas audit lainnya, atau kendala yang disebabkan oleh prosedur penyidikan atau kendala yang disebabkan permasalahan teknis hukum, atau terdapat permasalahan subjektif lainnya yang merupakan diskresi oleh instansi penyidik yang bertujuan untuk penegakan hukum atau penyelamatan keuangan Negara atau faktor lainnya sesuai fakta lapangan.

\footnotetext{
${ }^{1}$ https://manado.tribunnews.com/2015/03/10/kasus-korupsi-solar-cell-di-manado-terus-didalami-polisi https://manado.antaranews.com/berita/32879/ahli-sejak-pelelangan-solar-cell-menyalahi-aturan

${ }^{2}$ https://manado.tribunnews.com/2019/04/08/ini-tanggapan-kejati-sulut-mengenai-sidang-prapereradilan-kasuspemecah-ombak-likupang-minut http://kejari-manado.go.id/2018/06/01/kejati-sulut-tahan-tersangka-kasus-dugaan-korupsi-pemecah-ombak-likupang/
} 
Selama ini audit investigasi dan audit perhitungan kerugian keuangan Negara (PKKN) dianggap audit yang eksklusif dan bersifat rahasia, sehingga cenderung tertutup sehingga informasi tentang proses audit sangat minim hanya sebatas laporan hasil audit dan itu pun terbatas pendistribusiannya, sehingga prosedur audit investigasi tidak dapat diuji oleh pihak eksternal, dan audit PKKN baru bisa di uji di depan pengadilan, dengan adanya undang-undang nomor 14 tahun 2008 tentang keterbukaan informasi publik, memungkinkan untuk informasi proses audit dapat diberikan kepada pihak eksternal.

Tujuan yang ingin dicapai dari penelitian ini adalah untuk Menganalisis proses pemanfaatan laporan hasil audit forensik oleh Polisi, Jaksa dan Hakim, menganalisis tidak dimanfaatkan laporan hasil audit forensik oleh Polisi, Jaksa dan Hakim, menganalisis dampak, dari tidak dimanfaatkannya laporan hasil audit forensik oleh Polisi, Jaksa dan Hakim.

\section{Tinjauan Pustaka}

Perilaku korup (fraud) pada dasarnya merupakan sebuah fenomena sosiologis yang memiliki implikasi ekonomi dan politik. Robert K. Merton (1957) mengemukakan teorinya bahwa korupsi merupakan suatu perilaku manusia yang diakibatkan oleh tekanan sosial, sehingga menyebabkan pelanggaran norma-norma. Setiap sistem sosial memiliki tujuan dan manusia berusaha untuk mencapainya melalui cara-cara (means) yang telah disepakati.

Perilaku korup (fraud) pada dasarnya merupakan sebuah fenomena sosiologis yang memiliki implikasi ekonomi dan politik. Robert K. Merton (1957) mengemukakan teorinya bahwa korupsi merupakan suatu perilaku manusia yang diakibatkan oleh tekanan sosial, sehingga menyebabkan pelanggaran norma-norma. Setiap sistem sosial memiliki tujuan dan manusia berusaha untuk mencapainya melalui cara-cara (means) yang telah disepakati.

Akuntansi forensik muncul karena pesatnya perkembangan fraud yang terjadi, untuk mengungkapkan fraud tersebut diperlukan ilmu mengenai akuntansi forensik. Praktik akuntansi forensik di Indonesia sendiri tumbuh tidak lama setelah krisis ekonomi melanda Indonesia tahun 1997. Akuntansi forensik sesungguhnya bisa mempunyai peran yang efektif dalam menegakkan hukum di Indonesia, namun perannya masih belum maksimal. Saat ini Pusat Pelaporan dan Analisis Transaksi Keuangan (PPATK) berusaha untuk mengembangkan akuntansi forensik yang mulai berkembang di Indonesia.

Hal ini juga terjadi di Amerika Serikat dengan diundangkannya Sarbanes Oxley Act tahun 2002, merupakan salah satu pendorong dalam perkembangan akuntansi forensik. Dorongan ini juga diperkuat melalui Foreign Corrupt Practice Act, suatu organisasi yang mengkhususkan dirinya dalam bidang penanggulangan fraud dan korupsi. Untuk dapat mengungkap motif dan cara pelaku fraud dalam melakukan aksinya diperlukan orang-orang yang profesional yaitu mereka yang ahli di bidang akuntansi forensik.

Menurut Hopwood, W. S. Leiner, J. J. dan Young, G. R (2008:3), akuntansi forensik adalah aplikasi keterampilan investigasi dan analitik yang bertujuan untuk menyelesaikan masalah-masalah keuangan melalui cara-cara yang sesuai dengan standar yang ditetapkan oleh pengadilan dan hukum.

Tuanakotta (2012:4) mengemukakan bahwa akuntansi forensik adalah penerapan disiplin akuntansi dalam arti luas, termasuk auditing, pada masalah hukum untuk penyelesaian hukum di dalam atau di luar pengadilan. Akuntansi forensik dapat diterapkan di sektor publik maupun swasta, sehingga apabila memasukkan pihak yang berbeda, maka akuntansi forensik menurut Crumbley dalam Tuanakotta (2012:5) mengemukakan bahwa secara sederhana akuntansi forensik dapat dikatakan sebagai akuntansi yang akurat untuk tujuan hukum, atau akuntansi yang tahan uji dalam kancah perseteruan selama proses pengadilan, atau dalam proses peninjauan yudisial, atau tinjauan administratif.

\section{Penelitian Terdahulu}

Penelitian berjudul Effect of Forensic On the Management of Fraud in Microfinace Institutions In Cross River State. Berdasarkan analisis empiris, hasil regresi menunjukkan bahwa koefisien estimasi dari parameter regresi adalah semua tanda negatif. Implikasi dari 
tanda-tanda ini adalah bahwa keterlibatan aktif dari penyelidikan forensik dan dukungan litigasi mengurangi penipuan di bank-bank keuangan mikro terpilih di Calabar, Negara Bagian Cross River.

Penelitian berjudul Forensic Accounting And Fraud Investigation: An Empirical Study From Mauritius, dengan hasil: Penelitian ini dilakukan untuk mengevaluasi kesadaran akuntansi forensik di Mauritius dan perilaku berbagai jenis perusahaan sehubungan dengan akuntansi forensik dan dapat disimpulkan bahwa mayoritas variabel yang diteliti berhubungan positif dengan kesadaran akuntansi forensik. Penelitian ini dilakukan untuk menyelidiki kesadaran akuntansi forensik antara perusahaan akuntansi dan audit, perusahaan multinasional dan perusahaan lokal dari Mauritius.

Penelitian berjudul Advances and Issues in Fraud Research: A Commentary dengan hasil memberikan komentar ringkas tentang beberapa kemajuan dan masalah dalam penelitian penipuan berbasis akuntansi forensik. Kami mengamati bahwa penyelidikan akademis di bidang penelitian penipuan berkembang dan pengetahuan akuntansi forensik dapat mendukung kegiatan deteksi penipuan. Namun, teknik pengumpulan data dan alat-alat lain yang dikembangkan dari penelitian ilmu forensik memiliki kegunaan terbatas untuk praktik akuntansi forensik karena biaya besar, kompleksitas dan kekhawatiran keterampilan. Kami mengidentifikasi beberapa kemajuan dan masalah menarik dalam literatur dan memberikan beberapa arahan untuk penelitian di masa depan.

\section{Metode Penelitian}

Jenis penelitian yang digunakan dalam penelitian ini adalah jenis kualitatif. Menurut Sugiono (2017), penelitian kualitatif adalah untuk memahami dan mengeksplorasi fenomena utama objek yang diteliti, sehingga memperoleh pemahaman yang mendalam dan menemukan sesuatu yang unik. Langkah-langkah atau proses penelitian kualitatif bersifat artistic, sehingga tidak baku, dan akan tergantung pada tujuan penelitian. Langkah-langkah penelitian kualitatif bertujuan untuk mengkonstruksi fenomena baru dan menemukan hipotesis. ${ }^{3}$

Bila ditinjau dari tingkat eksplanasinya merupakan jenis penelitian eksploratif. Metode eksploratif dipandang sesuai, karena dalam pendekatan metode ini, penelitian yang dilaksanakan untuk menggali data dan informasi tentang topik atau isu-isu baru yang ditujukan untuk kepentingan pendalaman atau penelitian lanjutan. Tujuan penelitian adalah untuk merumuskan pertanyaanpertanyaan yang lebih akurat yang akan dijawab dalam penelitian lanjutan atau penelitian kemudian. Peneliti biasanya menggunakan penelitian eksplorasi ini untuk mendapatkan pengetahuan yang cukup dalam penyusunan desain dan pelaksanaan kajian lanjutan yang lebih sistematis.

Teknik pengumpulan data yang dilakukan dalam penelitian ini adalah wawancara, Observasi, dan studi dokumentasi atau gabungan ketiganya yang disebut triangulasi. Analisis data dalam penelitian kualitatif dilakukan sebelum memasuki lapangan, selama dilapangan, dan setelah selesai dilapangan. Miles and Huberman dalam (Sugiyono, 2017) mengemukakan aktifitas dalam analisis data kualitatif dilakukan secara interaktif dan berlangsung secara terus menerus sampai tuntas, sehingga datanya sudah jenuh. Aktivitas dalam analisis data mencakup, data reduction, data display, dan data conclusion drawing/verification. Prosedur pengolahan data yang telah dikumpulkan adalah sebagai berikut: (1) Membuat transkrip wawancara (interviews transcriptions), (2) Melakukan analisis data. Analisis data yang digunakan dalam penelitian ini menggunakan analisis isi (content analysis). Analisis isi dimulai dengan melakukan coding terhadap istilah-istilah atau penggunaan kata dan kalimat yang relevan, yang paling banyak muncul dalam media komunikasi.. Setelah dikategorikan kemudian dimasukkan ke dalam tema, (3) Melakukan Validitas data. Pengujian keabsahan data dilakukan dengan menyandingkan antara sumber data dengan data lainnya, yaitu data yang diperoleh dari hasil wawancara, observasi dan studi dokumentasi, (4) Mengambil kesimpulan dari hasil penelitian. Pengambilan kesimpulan berdasarkan analisis data yang telah diuji keabsahannya.

${ }^{3}$ Sugiono, Metode Penelitian Kualitatif, untuk penelitian yang bersifat: Eksploratif, Enterpretif, Interaktif dan Konstruktif, (Bandung: ALFABETA, 2017), hal. 23 


\section{Analisis dan Pembahasan}

Penelitian dilakukan pada bulan Mei hingga September 2019 dengan melakukan wawancara secara mendalam (in-depth interview) kepada informan yang berwenang dan berkaitan langsung dengan subjek penelitian untuk memperoleh informasi terkait yang dilakukan selama 30 sampai 60 menit. Data kualitatif berupa data primer diperoleh dari sumber informan yaitu Penyidik Polda Sulut, Penyidik Kejaksaan Tinggi Sulut, Penyidik Kejaksaan Negeri Bitung, Ketua Majelis Hakim Tipikor dan Hakim Adhock Pada Pengadilan Negeri Kelas IA Manado dan Koordinator Bidang Investigasi Pada Perwakilan BPKP Provinsi Sulawesi Utara. Kemudian data sekunder diperoleh melalui studi dokumen Laporan Hasil Audit, Putusan Persidangan dan dokumen penyelidikan dan penyidikan.

Berdasarkan studi dokumentasi, yang dimaksud dengan instansi penyidik secara umum adalah instansi Kepolisian dan instasi penuntut adalah Kejaksaan namun terkait dengan penangan tindak pidana korupsi, selain kepolisian, Kejaksaan juga dapat menjadi penyidik. Tugas dan fungsi jaksa sebagai penyidik tindak pidana korupsi. Sesuai dengan ketentuan Pasal 284 ayat (2) KUHAP dan Pasal 17 PP No. 27 Tahun 1983, Jaksa masih berwenang melakukan penyidikan terhadap tindak pidana khusus dalam hal ini tindak pidana korupsi. Pemberantasan korupsi adalah dengan mengandalkan diperlakukannya secara konsisten Undang-undang tentang pemberantasan tindak pidana korupsi No. 20 tahun 2001 tentang perubahan atas Undang-undang No, 31 tahun 1999 tentang pemberantasan tindak pidana korupsi. Jaksa sebagai penyidik merangkap sebagai penuntut umum dalam penanganan tindak pidana korupsi. Maka untuk menyelesaikan Tugas serta fungsi tersebut jaksa harus bekerja sama dengan pihak lain yang terkait seperti polisi, hakim, dan penasihat hukum karena dalam melakukan kerja sama dalam suatu aturan atau hukum yang sifatnya pasti.

Sedangkan instansi auditor adalah Badan Pemeriksa Keuangan (BPK) Republik Indonesia, Badan Pengawasan Keuangan dan Pembangunan (BPKP) Republik Indonesia dan Inspektorat Kementerian, Provinsi, Kabupaten/Kota seluruh Indonesia, namun dalam penelitian ini dilakukan pada Badan Pengawasan Keuangan dan Pembangunan (BPKP) Provinsi Sulawesi Utara.

\section{Proses Pembuktian Tindak Pidana Korupsi Pada Instansi Penyidik}

Proses Pembuktian Tindak Pidana dimulai laporan polisi atau pengaduan masyarakat (Dumas), dari laporan atau pengaduan tersebut dilakukan kajian sambil melakukan Pengumpulan Bahan dan Keterangan (Pulbaket), jika ditemukan indikasi awal penyimpangan maka dilanjutkan ke tahap penyelidikan dengan menerbitkan Surat Perintah Penyelidikan (Sprin Lidik), dalam tahap penyelidikan dilakukan perluasan ruang lingkup, penambahan bahan dan keterangan sebanyak-banyaknya, dan dalam praktiknya pada Kepolisian Daerah Sulawesi Utara dan seluruh Kepolisian Resor (Polres) dibawah-Nya dalam tahap ini telah mulai melakukan koordinasi dengan dengan instansi auditor dan ahli-ahli terkait seperti ahli konstruksi, ahli hukum, ahli teknik informasi dan lain-lain.

Koordinasi tersebut dilakukan untuk memudahkan dalam proses penyelidikan dan untuk menjaga agar penyelidikan tetap fokus pada : menemukan penyimpangan/perbuatan melawan hukum, identifikasi bukti, pengumpulan bukti, menetapkan fokus penyimpangan, penentuan fihak terkait dan nilai kerugian Negara/Daerah. Setelah dilakukan koordinasi dan disimpulkan terdapat indikasi kuat penyimpangan maka secara resmi Sub Direktorat Tipikor melalui Direktur Reskrim Khusus (Reskrimsus) melakukan permintaan untuk dilakukan audit investigasi kepada instansi auditor dan ahli yang terkait, biasanya para ahli melakukan tugasnya terlebih dahulu, karena prosedur lebih mudah atas keahlian personal, hasil dari pemeriksaan oleh ahli tersebut kemudian menjadi dokumen tambahan untuk melakukan koordinasi dengan instansi auditor, namun dalam praktiknya dapat dilakukan juga pemeriksaan ahli bersamaan dengan proses audit investigatif, karena biasanya auditor investigatif tidak terikat dengan hasil pemeriksaan ahli.

Setelah dilakukan koordinasi dan ekspose pada instansi auditor maka tim auditor melakukan audit investigatif, pelaksanaan audit investigatif tidak terikat dengan waktu, penyelesaian audit investigasi sangat tergantung pada proses pembuktian yang dilakukan tim audit, dalam proses audit tim penyelidik bertindak sebagai tim pendukung dalam pengumpulan bahan dan keterangan.

Menurut penjelasan informan, titik kritis pembuktian kasus TPK adalah pada saat proses audit investigatif, karena pada saat tersebut auditor dengan tim penyelidik bersinergi dalam menentukan penyimpangan/perbuatan melawan hukum, modus operandi, ruang lingkup dan pihak-pihak terkait, karena simpulan tersebutlah menjadi acuan dalam pembuktian pada tahap penyidikan dan pemberkasan.

Setelah laporan hasil audit investigatif diterima oleh tim penyelidik, dilakukan gelar perkara untuk menentukan kasus tersebut telah cukup bukti untuk dilanjutkan ke tahap penyidikan, setelah 
dinyatakan layak untuk ditingkatkan ke tahap penyidikan maka dilakukan penyesuaian berkas dan keterangan yang diperoleh oleh tim penyelidik dengan bukti-bukti audit yang ada dalam laporan hasil audit investigatif, setelah dianggap sesuai dan lengkap maka diusulkan untuk diterbitkan surat perintah penyidikan, dan Surat Pemberitahuan Dimulai Penyidikan (SPDP) dikirimkan kepada Kejaksaan dan Komisi Pemberantasan Korupsi (KPK).

Setelah diterbitkan surat perintah penyidikan biasanya dilanjutkan dengan penetapan tersangka, namun dalam beberapa kasus tidak dilakukan penetapan tersangka tergantung subjektivitas penyidik, kemudian untuk melengkapi berkas penyidikan salah satunya yakni bukti surat dari auditor, berupa Laporan Hasil Audit Perhitungan Kerugian Keuangan Negara (LHAPKKN), maka sebagai kelanjutan dari hasil audit investigatif kemudian tim penyidik kembali meminta secara resmi kepada instansi auditor untuk dapat melakukan audit Perhitungan Kerugian Keuangan Negara (PKKN), sambil mengonversi seluruh keterangan yang diperoleh pada tahap penyelidikan menjadi Berita Acara Pemeriksaan (BAP) dengan cara memeriksa seluruh fihak-fihak terkait.

Ada kalanya pada kasus tertentu, setelah dilakukan pengumpulan bahan dan keterangan tim merasa yakin dan cukup bukti untuk langsung ditingkatkan ke tahap penyidikan, maka prosesnya juga sama dengan penjelasan diatas. Jadi dapat disimpulkan bahwa pada instansi penyidik proses pembuktian dapat dilakukan mulai dari penyelidikan dan bisa langsung ke tahap penyidikan.

Namun tidak semua kasus dilakukan pemberkasan untuk dilimpahkan kepada instansi penutut, atau tidak semua kasus TPK berakhir dipengadilan, kasus dapat dihentikan pada tahap penyelidikan maupun pada tahap penyidikan dengan berbagai penyebab, diantaranya : pengembalian kerugian keuangan Negara, kasus tersebut ditangani instansi penyidik lainnya yaitu KPK atau kejaksaan, tersangka atau pihak terkait (saksi mahkota) meninggal dunia, atau alasan subjektif tertentu. Kondisi tersebut menyebabkan tidak semua laporan audit dimanfaatkan sampai ke peradilan, namun tetap dapat digunakan untuk menentukan jumlah kerugian keuangan negara yang harus dikembalikan.

\section{Proses Pembuktian Tidak Pidana Korupsi Pada Instansi Penuntut}

Wewenang Kejaksaan dalam penanganan perkara tindak pidana korupsi sebagaimana diatur dalam pasal 30 ayat (1) huruf d Undang-undang Nomor 16 tahun 2004 tentang Kejaksaan Republik Indonesia, menyatakan bahwa "Kejaksaan berwenang untuk melakukan penyidikan terhadap tindak pidana tertentu berdasarkan undang-undang"

Berbagai dasar hukum lain yang menjadi tuntunan bagi Kejaksaan dalam penanganan kasus korupsi sebagaimana tertuang dalam Pasal 284 ayat (2) KUHAP jo. Pasal 17 PP No. 27 Tahun 1983. Selanjutnya dalam TAP MPR RI No. XI/MPR/1998 tentang Penyelenggaraan Negara yang Bersih dan Bebas dari Korupsi, Kolusi dan Nepotisme (KKN) jo. Inpres No. 30 Tahun 1998 tanggal 02 Desember 1998 tentang Pemberantasan KKN, Undang-undang (UU) No. 28 Tahun 1999 tanggal 19 Mei 1999 tentang Penyelenggaraan Negara yang Bersih dan Bebas dari KKN, yang berisi antara lain kewenangan Jaksa sebagai Penyidik tercantum dalam Pasal 1, 12, 17, 18, 20, 21 dan 22 beserta penjelasannya.

Selanjutnya adalah PERJA R.I. Nomor PER-006/A/JA/07/2007 Tentang Organisasi dan Tata Kerja Kejaksaan Republik Indonesia dalam pasal 365 menyatakan bahwa, Jaksa Agung Muda Bidang Tindak Pidana Khusus mempunyai tugas dan wewenang melaksanakan tugas dan wewenang Kejaksaan bidang tindak pidana khusus meliputi penyelidikan, penyidikan, pra penuntutan, pemeriksaan tambahan, penuntutan, upaya hukum, pelaksanaan penetapan hakim dan putusan pengadilan yang telah mempunyai kekuatan hukum tetap, eksaminasi serta pengawasan terhadap pidana bersyarat dan keputusan lepas bersyarat dalam perkara tindak pidana khusus serta hukum lainnya.

Kejaksaan diharapkan sebagai garda terdepan dalam pemberantasan korupsi karena Kejaksaan memegang posisi sentral dalam penegakan hukum. Posisi sentral disebabkan tugas dan wewenang yang dimiliki oleh Kejaksaan, di mana Kejaksaan yang menentukan apakah suatu kasus layak atau tidak ditingkatkan ke penuntutan. Dimana pemeriksaan sidang di Pengadilan adalah merupakan gerbang bagi pencari keadilan untuk menemukan kebenaran dan keadilan yang sesungguhnya.

Terkait sumber informasi yang diperoleh oleh Kejaksaan mengenai adanya dugaan tindak pidana korupsi bisa didapatkan melalui Pencarian sendiri/mengembangkan informasi sendiri, Memperoleh informasi dari masyarakat, Menindaklanjuti hasil temuan dari Badan Pemeriksa Keuangan dan Pembangunan (BPKP), Aparat Pengawasan Internal Pemerintah (APIP) baik di pusat maupun daerah dan Badan Pengawas Keuangan (BPK). 
Dalam melakukan penangan terhadap perkara tindak pidana korupsi, tahapan yang dilakukan antara lain secara umum dimulai dari pengumpulan data/informasi, tahap penyelidikan, tahap penyidikan, tahap pra penuntutan, sampai pada tahap penuntutan.

\section{Pengumpulan data/informasi}

Berdasarkan Keputusan Jaksa Agung Republik Indonesia Nomor Kep-552/A/JA/10/2002 tentang Administrasi Intelijen Yustisial Kejaksaan disebutkan bahwa pengumpulan bahan keterangan, data, bukti terhadap gejala, indikasi pelanggaran ketentuan perundang-undangan yang berlaku melalui Operasi Intelijen Yustisial yang didukung oleh Surat Perintah Operasi Intelijen Yustisial. Setelah ditelaah, apabila hasilnya lengkap dan setelah melalui proses ekspose atau gelar perkara di instansi Kejaksaan dengan dihadiri oleh Jaksa-jaksa baik struktural maupun fungsional maka dapat ditingkatkan menjadi penyelidikan atau dihentikan.

\section{Tahap penyelidikan}

Penyelidikan berarti serangkaian tindakan mencari dan menemukan sesuatu keadaan atau peristiwa yang berhubungan dengan kejahatan dan pelanggaran tindak pidana atau yang diduga sebagai perbuatan pidana. Berdasarkan Keputusan Jaksa Agung Republik Indonesia Nomor Kep518/A/JA/11/2001 tanggal 01 Nopember 2001 secara administratif dikeluarkan Surat Perintah Penyelidikan (P-2) oleh Kepala Kejaksaan Negeri dengan menunjuk Jaksa Penyelidik yang bertugas melaksanakan penyelidikan atas kebenaran informasi yang didapat dari Intelijen maupun masyarakat. Apabila dipandang cukup bukti maka Tim Jaksa Penyelidik melalui gelar perkara (ekspose) dapat menentukan/menetapkan tersangka dan meneruskan perkara ke tahap penyidikan. Sebaliknya jika dipandang tidak cukup bukti, maka dapat dihentikannya penyelidikan.

Menurut informan, untuk Kejaksaan Tinggi Sulawesi Utara dan Kejaksaan Negeri dibawahnya belum pernah dilakukan proses penyelidikan kasus TPK dengan melibatkan auditor untuk melaksanakan audit investigatif atau menggunakan Laporan Hasil Audit Investigatif sebagai bukti untuk menaikkan ke tahap penyidikan.

\section{Tahap penyidikan}

Berdasarkan Pasal 1 ayat (2) KUHAP, penyidikan adalah serangkaian tindakan penyidik dalam hal dan menurut cara yang diatur dalam undang-undang untuk mencari serta mengumpulkan bukti yang dengan bukti itu membuat terang tentang tindak pidana yang terjadi dan guna menemukan tersangkanya.

Secara teknis kinerja penyidikan ditangani oleh bidang Tindak Pidana Khusus yang secara administratif mengeluarkan Surat Perintah Penyidikan di mana menugaskan beberapa Jaksa untuk melakukan penyidikan terhadap dugaan tindak pidana korupsi yang terjadi.

Dalam penyidikan Kejaksaan melakukan beberapa kegiatan di antaranya :

1) Pemanggilan saksi-saksi dan tersangka yang dalam format surat biasa disebut P-9 dengan tujuan mendengar dan memeriksa seseorang sebagai saksi atau tersangka dalam perkara tindak pidana korupsi tertentu dan atas nama tersangka tertentu. Penyampaian surat panggilan selambatlambatnya 3 hari sebelum yang bersangkutan harus menghadap;

2) Dapat melakukan permintaan bantuan keterangan ahli (P-10) di mana penyidikan dapat menghadirkan ahli untuk memperkuat pembuktian, dalam hal ini ahli yang dimintakan bantuan jika terkait kerugian keuangan negara adalah ahli auditor dari BPKP, BPK, atau Auditor Independen yang kemudian hasil dari pemeriksaan ahli tersebut berupa Laporan Hasil Pemeriksaan yang ada/tidaknya kerugian keuangan negara yang kemudian dijadikan salah satu dasar bagi penyidik untuk melengkapi bukti dalam tahapan penyidikan;

3) Dapat melakukan penangkapan, penahanan, penggeledahan, penyitaan dan tindakan hukum lain yang menurut hukum yang bertanggungjawab (Pasal 7 ayat (1) KUHAP);

4) Dapat menentukan/menemukan tersangka baru;

5) Apabila berkas sudah lengkap, maka penyidik sesuai dengan Pasal 8 ayat (2) dan (3) KUHAP, dapat menyerahkan berkas perkara kepada penuntut umum melalui dua tahap yaitu, Tahap pertama hanya menyerahkan berkas perkara; Tahap kedua penyidik menyerahkan tanggungjawab tersangka dan barang bukti kepada penuntut umum;

6) Apabila tidak terdapat cukup bukti maka dapat dikeluarkan SP 3 (surat ketetapan dihentikannya suatu penyidikan perkara pidana) dan dikirim ke instansi lain. 
Pada tahap ini melalui Asisten Tindak Pidana Khusus (Aspidsus) tim penyidik meminta instansi auditor untuk melakukan audit Perhitungan Kerugian Keuangan Negara (PKKN), seluruh permintaan audit dari Kejaksaan di Sulawesi Utara adalah audit ini, hal ini menjelaskan bahwa pembuktian tindak pidana korupsi pada Kejaksaan di Sulawesi Utara langsung pada tahap penyidikan. Hal ini juga dimungkinkan karena struktur organisasi Kejaksaan yang memisahkan antara fungsi penyelidikan dengan fungsi penyidikan, dimana Asisten Intelijen (Asintel) melaksanakan fungsi penyelidikan dan Aspidsus menyelenggarkan fungsi Penyidikan, sedangkan pada instansi penyidik, kedua fungsi tersebut

Pada tahap ini Laporan Hasil Audit Perhitungan Kerugian Keuangan Negara (LHAPKKN), dijadikan sebagai salah satu bukti, yaitu bukti surat, dalam praktiknya pada tahap ini penyidik dan auditor sangat intens berinteraksi, karena dalam audit tersebut beban pembuktian sepenuhnya menjadi tanggung jawab penyidik, sedangkan auditor menentukan bukti yang diperlukan untuk menghitung kerugian keuangan negara.

Kompetensi suatu bukti dalam mengestimasi atas adanya jumlah kerugian negara menentukan formula adanya tindak pidana korupsi, tanpa adanya kerugian keuangan negara meskipun telah terjadi salah prosedur tentu tidak bisa dikategorikan sebagai tindak pidana korupsi (hanya sebatas kesalahan administratif) (Achsin, 2010).

\section{Tahap pra penuntutan}

Dalam Pra Penuntutan, setelah adanya SPDP (Surat Perintah Dimulainya Penyidikan) baik yang berasal dari penyidik kepolisian maupun penyidik Kejaksaan, maka akan ditunjuk seorang Jaksa untuk mengikuti perkembangan penyidikan (P-16) memeriksa berkas perkara tahap pertama yang diajukan oleh penyidik. Apabila dianggap kurang lengkap maka Jaksa penuntut umum segera mengembalikan berkas perkara kepada penyidik disertai petunjuk untuk dilengkapi (P-19). Berdasarkan pasal 138 KUHAP bahwa dalam waktu 14 hari setelah berkas diterima dari penuntut umum penyidik harus sudah menyampaikan kembali berkas perkara itu ke penuntut umum. Dalam hal penuntut umum berpendapat bahwa berkas sudah lengkap, maka penuntut umum secara teknis di Kejaksaan membuat P-21 atau menyatakan bahwa hasil penyidikan sudah lengkap dan segera penyidik menyerahkan barang bukti dan tersangkanya kepada penuntut umum.

Sebaliknya, berdasarkan pasal 110 KUHAP, apabila dalam waktu empat belas hari penuntut umum tidak mengembalikan berkas perkara maka penyidikan dianggap selesai.

\subsubsection{Tahap penuntutan}

Berdasarkan pasal 1 ayat (7) KUHAP, penuntutan adalah tindakan penuntut umum untuk melimpahkan perkara pidana ke Pengadilan Negeri yang berwenang dalam hal dan menurut cara yang diatur dalam undang-undang dengan permintaan supaya diperiksa dan diputus oleh hakim di sidang pengadilan.

Pada tahap penuntutan, Kejaksaan membuat surat P-16A yaitu Penunjukan Jaksa Penuntut Umum (JPU) untuk Penyelesaian Perkara Tindak Pidana. Segera setelah itu JPU membuat surat dakwaan (P-29) dan segera melimpahkan dakwaan, berkas perkara, beserta barang bukti ke Pengadilan Tipikor / Pengadilan Negeri (P-31) dengan permintaan agar segera mengadili. Apabila Ketua Pengadilan menyatakan berwenang untuk mengadili maka segera menentukan hari sidang.

Jaksa Penuntut Umum bertugas untuk membuktikan dakwaannya, kecuali diatur tertentu oleh undang-undang seperti pembuktian terbalik dalam pemberian gratifikasi. Apabila telah sampai pada penetapan ketua Pengadilan Negeri / Hakim, maka JPU berwenang untuk membacakan tuntutan (P42). Setelah adanya putusan, jika sikap dari kedua belah pihak menerima, maka akan dilanjutkan dengan Eksekusi. Namun apabila sikap kedua belah pihak tidak menerima, maka dapat dilakukan upaya hukum berupa banding, kasasi, kasasi demi kepentingan hukum, garasi, dan peninjauan kembali.

\section{Proses Audit Forensik Pada Institusi Auditor}

Proses audit forensik pada Perwakilan BPKP Provinsi Sulawesi Utara mengacu pada Peraturan Kepala BPKP Nomor 1314 Tahun 2012 tentang Pedoman Penugasan Bidang Investigasi sebagai mana telah di ubah dengan Peraturan Kepala BPKP Nomor 17 Tahun 2017 tentang Pedoman Pengelolaan Kegiatan Bidang Investigasi. Ketentuan tersebut merupakan petunjuk pelaksanaan administratif proses audit, sedangkan prosedur audit mengacu pada standar audit forensik mengacu pada Atribut dan Kode Etik Auditor Forensik serat Standar Audit Investigatif, berikut disajikan tahapan proses audit: 


\section{Tahap Pra Perencanaan}

Berdasarkan hasil observasi terhadap proses bisnis pada bidang investigasi Perwakilan BPKP Provinsi Sulawesi Utara audit forensik dimulai dari surat permintaan dari instansi penyidik, surat tersebut ditujukan kepada Kepala Perwakilan BPKP Provinsi Sulawesi Utara, kemudian kepala perwakilan mendisposisikan surat tersebut kepada Koordinator Pengawasan Bidang Investigasi, permintaan tersebut bisa berupa audit investigatif (jika kasus tersebut dalam tahap penyelidikan) atau audit Perhitungan Kerugian Keuangan Negara PKKN jika kasus dalam tahap penyelidikan. Kemudian dalam tempo satu sampai dengan tiga hari, surat permintaan tersebut dijawab dengan surat undangan untuk melakukan ekspose atas kasus tersebut, jangka waktu diterimanya surat tersebut oleh penyidik dapat berbeda-beda tergantung komunikasi dan kecepatan pengiriman. Kemudian Perwakilan BPKP Provinsi Sulawesi Utara menunggu kesiapan instansi penyidik dalam melakukan ekspose sambil melakukan koordinasi lisan antara auditor dengan penyidik, tidak ada batasan waktu dalam tahap ini, tahapan ini sangat ditentukan oleh kesiapan instansi penyidik dalam beberapa kondisi sampai melampaui tahun anggaran.

Jika telah ada konfirmasi kesiapan dari penyidik maka dilakukan penjadwalan untuk ekspose, lokasi dan waktu tergantung kesepakatan antara auditor dengan penyidik, untuk lokasi, dapat dilakukan di instansi penyidik atau di instansi auditor, kemudian dilakukan ekspose dimana kegiatan tersebut pada intinya penyidikan diwajibkan memaparkan kasus posisi atau proses dugaan penyimpangan yang telah ditemukan penyidik, pada tahap ini dilakukan diskusi dengan auditor untuk hal-hal yang kurang jelas dan penambahan kebutuhan dokumen yang diperlukan untuk memperkuat pembuktian, dalam proses ini auditor menerapkan kriteria untuk dapat menerima hasil ekspose tersebut

Jika telah memenuhi kriteria tersebut maka hasil ekspose dapat disimpulkan untuk disepakati akan dilakukan audit dalam bentuk berita acara kesepakatan hasil ekspose, namun jika belum memenuhi kriteria tersebut maka tetap dibuatkan berita acara kesepakatan dengan catatan untuk menunda dilakukan audit sampai terpenuhi catatan hasil ekspose tersebut.

Secara prosedur tidak ada batasan frekuensi pelaksanaan ekspose, artinya ekspose dapat dilakukan berkali-kali untuk satu kasus, sampai diperoleh kesepakatan untuk dilakukan audit. Ekspose bertujuan untuk mendapatkan pemahaman bersama secara komprehensif antara penyidik dan auditor tentang suatu kasus, sehingga memudahkan proses pembuktian dalam audit.

\section{Tahap Perencanaan}

Setelah hasil ekspose disepakati untuk dilakukan proses audit, kemudian auditor menetapkan sasaran dan ruang lingkup audit, untuk audit investigatif dilakukan pengembangan hipotesis untuk mengarahkan proses pembuktian dan penyimpangan, mengidentifikasi pendekatan, prosedur dan teknik audit yang akan digunakan untuk menemukan dan menguji penyimpangan, merumuskan langkah kerja dan prosedur dalam bentuk program audit, melakukan penilaian risiko penugasan dan merencanakan mitigasi risiko yang memadai, serta menyusun surat tugas.

\section{Tahap Pelaksanaan}

Pelaksanaan audit pada intinya adalah penggunaan berbagai prosedur dan metode untuk mengumpulkan bukti yang memenuhi kriteria relevan, kompeten dan cukup, dalam tahap ini tim audit juga dibantu oleh tim penyelidik dan tim penyidik, untuk kegiatan tertentu jika dibutuhkan tim audit dapat meminta bantuan tenaga ahli untuk menyimpulkan hal-hal yang berada diluar ranah kompetensi auditor. Untuk audit investigatif tim audit cenderung memperoleh bukti sendiri dengan dibantu tim penyelidik, namun untuk audit perhitungan kerugian keuangan negara seluruh bukti diperoleh dari tim penyidik

Secara umum pelaksanaan penugasan audit forensik di BPKP Perwakilan Provinsi Sulawesi Utara mengacu pada standar pelaksanaan baku dan manajemen kendali mutu yang sangat ketat, namun terhadap hasil laporan audit forensik tanggung jawab BPKP adalah samapi dengan laporan audit forensik diterbitkan dan apabila diperlukan dapat meberikan keterangan ahli didepan persidangan sesuai dengan fakta hasil audit dan keahlian profesi auditor yang bersangkutan. tidak diatur mekanisme pemantauan atantar instansi, biasanya informasi pemanfaatan laporan didapat secara lisan dari penyidik dan merupakan informasi non formal.

\section{Pemberian Keterangan Ahli Oleh Auditor Forensik Pada Institusi Peradilan}

Pemberian keterangan ahli dipengadilan merupakan kegiatan lanjutan dari pertanggungjawaban atas Laporan Hasil Audit Perhitungan Kerugian Keuangan Negara (LHAPKKN), 
kegiatan ini berdasarkan pada panggilan secara hukum oleh penuntut umum, pemberian keterangan ahli didepan persidangan adalah salah satu bukti hukum, sehingga auditor yang melakukannya harus disumpah sesuai agama dan kepercayaannya.

Setelah memperoleh surat panggilan untuk hadir di persidangan, auditor menyiapkan surat tugas untuk hadir pada hari yang jadwal yang telah ditentukan, jika terjadi perubahan jadwal mendadak biasanya jaksa penuntut umum memberitahukan secara lisan, walaupun kehadiran auditor sebagai pemberi keterangan ahli atas panggilan jaksa, namun kehadiran auditor didepan pengadilan adalah independen, tidak dipengaruhi oleh siapa pun melainkan hanya menjelaskan laporan audit dan hal-hal yang diketahui secara keilmuan dan keahlian.

Untuk hadir dalam ruang persidangan atas izin dari hakim, pertama-tam hakim akan memeriksa kesesuaian identitas ahli (Curikulum Vitae) yang hadir dengan yang ada dalam berita acara pemeriksaan, kemudian hakim bertanya kepada ahli, apakah bersedia untuk disumpah?, jika bersedia kemudian hakim membacakan pernyataan sumpah dengan dikuti oleh ahli, sesuai dengan tatacara agama ahli, setelah disumpah kemudian hakim mulai bertanya kepada ahli terkait keahlian dan keilmuan ahli, setalah hakim bertanya kemudian diberikan kesempatan kepada jaksa penuntut umum, kemudian baru pengacara, yang pada intinya ahli memberikan keterangan untuk membuat terang perkara tersebut sehingga menambah keyakinan para hakim dalam menentukan vonis.

Atas penjelasan informan diatas dapat disimpulkan bahwa, kegiatan audit investigatif dan audit forensik yang dilakukan auditor ditambah pemberian keterangan ahli didepan pengadilan sangat membantu proses pembuktian tindak pidana korupsi, dimana kegiatan tersebut sangat membantu pihak penyelidik, penyidik, penuntut dan hakim. Kepiawaian auditor dalam berkomunikasi verbal dalam persidangan, membuat perkara menjadi terang manakala auditor sanggup memberikan keterangan yang lengkap, jelas dan cermat serta keterangan tersebut dapat ditangkap secara sempurna oleh para pihak yang terperkara (Achsin, 2010).

Para profesional harus menggunakan keahlian profesionalnya dengan cermat dan seksama (due profesional care) dan secara hati-hati (prudent) dalam setiap penugasan, hal tersebut ditegaskan dalam Peraturan Menteri Negara Pendayagunaan Aparatur Negara tentang Standar Umum APIP No. 2300 Kecermatan Profesional. Due Profesional Care ini dilakukan dalam penugasan Penghitungan Kerugian Keuangan Negara (PKKN), karena keputusan awal atas dapat atau tidaknya perkara dilanjutkan dengan bantuan PKKN tidak diputuskan oleh individu atau Tim Auditor, namun dari seluruh staff Deputi Investigasi BPKP (Achsin, 2010).

\section{Penutup}

Berdasarkan hasil penelitian dan pembahasan yang telah dikemukakan, maka penulis menarik beberapa kesimpulan sebagai berikut : 1) Pembuktian tindak pidana korupsi dibutuhkan kerjasama yang baik antara tim penyidik dan tim auditor forensik. 2) Pada setiap tahap pembuktian tindak pidana korupsi dapat dilakukan dengan pendekatan audit, baik Audit Investigatif (AI) maupun Audit Perhitungan Kerugian Keuangan Negara (APKKN), dengan melibatkan peran auditor sedini mungkin, pembuktian tindak pidana korupsi akan lebih komprehensif, tidak bias dan memudahkan dalam proses peradilan. 3) Kegiatan penyelidikan dapat dilakukan secara paralel dengan kegiatan audit investigatif, tim penyelidik dapat bersinergi dengan tim auditor sehingga pembuktian tindak pidana korupsi lebih cepat, tepat dan efektif sampai dengan proses peradilan. 4) Laporan hasil audit, baik Laporan Hasil Audit Investigatif (LHAI) maupun Laporan Hasil Audit Perhitungan Kerugian Keuangan Negara (LHAPKKN) secara formal sangat dibutuhkan oleh tim penyelidik maupun tim penyidik, baik sebagai bukti awal maupun bukti lanjutan (bukti surat dalam berkas dakwaan) dan pemberian keterangan ahli didepan persidangan yang dapat membantu hakim dalam membuat putusan. 5) Tidak semua kegiatan penyelidikan dan kegiatan penyidikan berakhir di proses peradilan, dapat dilakukan penghentian pada masing-masing tahap tersebut dengan berbagai alasan dan kondisi yakni : pengembalian kerugian keuangan Negara, kasus tersebut ditangani instansi penyidik lainnya yaitu KPK atau kejaksaan, tersangka atau pihak terkait (saksi mahkota) meninggal dunia, atau alasan subjektif tertentu. Kondisi tersebut menyebabkan tidak semua laporan audit dimanfaatkan sampai ke peradilan, namun tetap dapat digunakan untuk menentukan jumlah kerugian keuangan negara yang harus dikembalikan. 6) Tidak ditemukan dampak atas tidak dimanfatkannya laporan hasil audit forensik, baik dalam institusi penegak hukum maupun dari instansi auditor, karena masing-masing institusi memiliki kewenangan yang tidak saling mempengaruhi.

Berdasarkan hasil penelitian dan pembahasan yang telah dikemukakan, maka penulis memberikan beberapa saran sebagai berikut : 1) Dimasa mendatang pemanfaatan Audit investigatif 
dapat dioptimalkan untuk berbagai keperluan, selain untuk keperluan penyelidikan juga dapat digunakan untuk keperluan baik untuk kebutuhan litigasi maupun non litigasi. 2) Kegiatan audit investigatif dapat dijadikan alat untuk penyelamatan aset negara maupun perusahaan, untuk menghindari proses peradilan

\section{Daftar Pustaka}

Achsin, 2010. Visum Akuntansi Forensik Dalam Tindak Pidana Korupsi. Disertasi. Malang : Fakultas Ekonomi - Universitas Brawijaya.

Bassey Eyo Bassey, 2018. Effect of Forensic On the Management of Faraud in Microfinace Institutions In Cross River State

Hopwood, W. S. Leiner, J. J. \& Young, G. R. 2008. Forensic Accounting. New York, : McGraw - Hill/ Irwin Companies.

Merton. Robert K. 1967. On theoretical sociology. New York: The Free Press.

Sarbanes-Oxley Act of 2002, Section 302, Section 404

Sugiyono, 2017. Metode Penelitian Kuantitatif, Kualitatif dan R\&D. Bandung: Alfabeta.

Peterson K Ozili, 2018. Advances and Issues in Fraud Research: A Commentary

Tuanakotta, 2013. Audit Berbasis ISA (International Standards on Auditing). Jakarta: Salemba Empat.

Tuanakotta, 2012. Akuntansi Forensik dan Audit Investigatif. Jakarta: Edisi 2, Salemba Empat.

Tuanakotta, 2013. Berpikir Kritis dalam Auditing. Jakarta: Salemba Empat.

Tuanakotta, 2009. Menghitung Kerugian Keuangan Negara dalam Tindak Pidana Korupsi. Jakarta: Salemba Empat.

Kitab Undang-undang Hukum Acara Pidana (KUHAP).

, Keputusan Jaksa Agung Republik Indonesia Nomor Kep-518/A/JA/11/2001 tanggal 01 Nopember 2001.

, Keputusan Jaksa Agung Republik Indonesia Nomor Kep-552/A/JA/10/2002 tentang Administrasi Intelijen Yustisial Kejaksaan.

Peraturan Kepala BPKP Nomor 17 Tahun 2017 tentang Pedoman Pengelolaan Kegiatan Bidang Investigasi.

https://manado.tribunnews.com/2015/03/10/kasus-korupsi-solar-cell-di-manado-terus-didalami-polisi

https://manado.antaranews.com/berita/32879/ahli-sejak-pelelangan-solar-cell-menyalahi-aturan

https://manado.tribunnews.com/2019/04/08/ini-tanggapan-kejati-sulut-mengenai-sidang-prapereradilan-kasus-pemecahombak-likupang-minut

http://kejari-manado.go.id/2018/06/01/kejati-sulut-tahan-tersangka-kasus-dugaan-korupsi-pemecah-ombak-likupang/ 